HOW

Volume 29, Number 1, pages 194 - 211

https://doi.org/10.19183/how.29.1.608

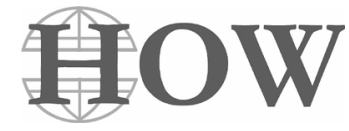

\title{
Knowledge-Base in ELT Education: \\ A Narrative-Driven Discussion
}

\author{
Conocimiento Base en la Formación en Lengua Extranjera: \\ Una Discusión Basada en Narrativas
}

\author{
Angela Castro-Garces ${ }^{1}$ \\ Universidad del Cauca, Popayán, Colombia
}

\begin{abstract}
Knowledge and experience, mediated by reflection, are essential components in teacher education and development programs. This paper discusses core elements that have guided ELT education in the last years and analyzes the case of five English language teacher educators who -in the Colombian context-reflect on their own pedagogical practices through narrative. I guide the discussion by four probing questions that generate a reflective overview of English language teachers' knowledge-base, identity construction, and decision-making when it comes to localizing knowledge. This reflection uncovers teacher educators' gains and challenges as it becomes input for those others who are at different stages of their teaching career.
\end{abstract}

Keywords: knowledge-base, narrative, reflection, teacher education

\section{Resumen}

El conocimiento y la experiencia, mediados por la reflexión, son componentes esenciales en los programas de formación y desarrollo docente. Este artículo discute elementos centrales que han guiado la educación en lengua extranjera en los últimos años y analiza los casos de cuatro formadores de docentes de inglés que -en el contexto colombiano- reflexionan sobre su propia práctica pedagógica por medio de narrativas. La discusión se guio por cuatro preguntas generadoras que dan una visión general reflexiva de los conocimientos base de los profesores de inglés, la construcción de identidad y la toma

She has a B.A. in Modern Languages, a Specialization in Pedagogy of Reading and Writing, and an M.A. in TESOL. She is a Ph.D. student at Universidad del Valle, and a Professor at Universidad del Cauca. Her research interests include teachers' professional development, literacy studies and intercultural communication. aycastro@unicauca.edu.co

ORCID ID: https://orcid.org/0000-0001-6675-0937

Received: September 4th, 2020. Accepted: October 13th, 2021.

This article is licensed under a Creative Commons Attribution-Non-Commercial-No-Derivatives 4.0 International License. License Deed can be consulted at https://creativecommons.org/licenses/by-nc-nd/4.0. 
de decisiones cuando se trata de localizar el conocimiento. Esta reflexión pone al descubierto logros y desafíos de formadores de docentes y se convierte en un insumo para aquellos que se encuentran en diferentes etapas de su carrera docente.

Palabras clave: conocimiento base, narrativas, reflexión, formación docente

\section{Introduction}

Teachers' inquiry and reflection are at the root of teacher education and professional development. No matter how novice or expert teachers seem to be, there is always a need for reflecting on our teaching practices. Having a strong theoretical basis, although essential, is never enough for teaching that is inclusive and "context-bound" (Kumaravadivelu, 2001); teaching that comes from the needs of learners and that is informed by teachers' understanding of local realities. Language teaching, mediated by reflection, provides pedagogical resources for teachers' empowerment and enactment that will help improve their practices.

In this sense, I strongly believe in the "transformative power of narrative" (Johnson \& Golombek, 2011) as a means to refine and be more engaged with the teaching profession. The need for inquiry and the richness of telling teachers' stories are a possibility that could be granted to them through study groups and teacher development programs, which take place over long periods with the purpose of acknowledging their roles and recognizing their contexts. Johnson and Golombek (2011) identify the role of narrative in reflective teaching, teacher inquiry, and the enhancement of teacher professional development, "not by the products of narrative activity, but by the cognitive processes that are ignited as a result of engagement in narrative" (p. 488). They introduce narrative as a possibility for externalizing, verbalizing, and examining teacher cognition. As further support for this premise, the Nigerian writer Chimamanda Adichie (2009) argues that stories matter; they depend on how they are told and who tells them. That is to say, that if stories are told by their authors, based on their own experiences, their reality is more likely to be perceived the way they want it to be, and those stories may, subsequently, have a healing, reflective, or empowering effect. In the same line, Durán, Lastra, and Morales (2013) value the role of retelling personal stories as a possibility for pre-service English teachers to share knowledge and gain experience.

The goal of this paper is to discuss core elements that have guided ELT education in the last years, including terms such as English as a Lingua Franca, English as an International Language, World Englishes (Canagarajah, 2005; Kubanyiova, 2018; Kumaravadivelu, 2012; McKay, 2018; Sifakis, 2007) and the implications for teacher decision-making on global and local issues that influence their practices. I also analyze the case of five Colombian English language teacher educators who reflect on their own pedagogical practices through narratives. They are: Marcela, Carmen, Paul, Ariadna, and Elijah. This reflection is guided by the following four probing questions: 
- When and how did you become an English teacher?

- How did you develop your teaching identity?

- What knowledge has made you become the kind of teacher you are?

- What are some sociocultural and global issues behind teaching English?

\section{Discussion}

\section{When and How Do We Become English Teachers?}

As a teacher educator, I analyze the possibility of helping prospective teachers become reflective practitioners. In doing so, I recall Freeman (2016), who invites us teacher educators to reflect upon the processes we live ever since we plan to be teachers. He introduces the terms social practice theory and situated learning theory to refer to the ways we approach learning. The first one is closer to the Vygotskian sociocultural theory, which I mostly adhere to, given I find learning to be situated in a specific context. Freeman (2016) introduces the born/ made dichotomy, which may place educators on one edge, either born to be teachers or made through education and experience. As teacher educators, we could wonder if it is possible to have building components of each, supported on Dewey's (1916) thoughts that the born/ made dichotomy blurs how people learn.

Another point of discussion is the background knowledge that we, teacher educators, bring to teaching, gained from our experience as students or from common everyday practices. Background knowledge is an ongoing debate in language teaching when referring to the language skills of teachers, and raises the concern of the value of the native speakers (NS), the definition of who is a legitimate one, and how much they are appreciated in this profession. This is aligned with the born/made dichotomy, which supports the demands that teachers have to fulfill because of their nonnative speaker (NNS) condition, while some others are exonerated because of their NS nature.

As such, many of us NNS teachers of English claim that we should not be measured based on nativelike abilities, but on how prepared we are to teach the language (Arboleda \& Castro, 2012; De Mejía, 2006; Espinosa-Vargas, 2019; Viáfara, 2016). For instance, EspinosaVargas (2019) addresses the NS/NNS dichotomy and questions the favoring of the first in the Colombian context. Conversely, Viáfara (2016) explores pre-service teachers' own perceived strengths and limitations based on their NS/NNS conditions for teaching the English language. Not surprisingly, while learning the language, we commonly try to mirror NSs' pronunciation in the attempt to reach a level of proficiency with a target in mind. When that is the case, whom are we imitating? Prospective teachers will rely on teacher educators, while the latter will make decisions based on their own education process and on 
the current waves that they have affiliated with after years of experience. Therefore, we need to get academically prepared to face the challenges of education, which imply localizing and contextualizing our teaching practices to make informed decisions that will help level up the NS/NNS conditions, so that other quintessential elements in teacher education programs are similarly valued.

I continue the discussion from the voices of five teacher educators who enrich this reflection through their narratives nurtured by their over 20 years of teaching experience. The five teachers whose cases I present here work for language teacher education programs in Colombia and acknowledge this one as an opportunity to reflect upon and rethink their practices. Following are some excerpts from their stories.

\begin{tabular}{|c|c|}
\hline \multicolumn{2}{|r|}{ When and how did you become an English teacher? } \\
\hline Marcela & $\begin{array}{l}\text { I became an English teacher after my international sojourn in 1998. Once I arrived } \\
\text { to my city, I applied for teaching positions at two Universities and I got both jobs. }\end{array}$ \\
\hline Carmen & $\begin{array}{l}\text { As a matter of fact, I started teaching English when I was in sixth semester, in } \\
\text { 1988. I remember that I taught a group of professionals enrolled to extension } \\
\text { courses at my university, which was a challenging and enriching experience. } \\
\text { Later, in 1991, I graduated from the Modern Languages Program and had the } \\
\text { opportunity to work as an English teacher in the same program, which contributed } \\
\text { a lot to my professional growth. I think that I didn't become an English teacher } \\
\text { once I graduated, but before that, since, for me, this profession derives from the } \\
\text { learning experiences and the chances you have to share them with other learners. }\end{array}$ \\
\hline Paul & $\begin{array}{l}\text { I think I became an English teacher when I started working at a school after } \\
\text { graduating from college. There, I had the entire responsibility of teaching classes } \\
\text { and dealing with the matters of a full-time teacher. It was back in } 1988 .\end{array}$ \\
\hline Ariadna & $\begin{array}{l}\text { I become a teacher } 21 \text { years ago when I was a university student } \\
\text { because in that moment [,] I had the opportunity to get into a } \\
\text { classroom. It was in a primary school and this experience was very } \\
\text { important because I realized that teaching was my life decision. }\end{array}$ \\
\hline Elijah & $\begin{array}{l}\text { I think I became an English teacher some time before finishing college. At that } \\
\text { time, undergraduate students were able to do their teaching practice in some } \\
\text { English courses at the university where I studied. So, I decided to take the } \\
\text { opportunity and that is how I became an English teacher. Right after I graduated } \\
\text { from college, I applied for a job at the same University and fortunately I got } \\
\text { it. Since then, I have been teaching at the University for more than } 20 \text { years. }\end{array}$ \\
\hline
\end{tabular}

Marcela and Paul assert that becoming English language teachers came to be once they got teaching jobs. Marcela, for instance, felt that her international sojourn helped her better her language skills, an aspect that recruiters appreciate. Carmen, instead, acknowledges that all 
the learning experiences she lived during her undergraduate program were part of becoming an English teacher, which means teaching is an ontological constituent of her persona.

Ariadna, like Carmen, had the chance to teach while being an undergraduate student, which was essential for both of them to reassure their career choice. Ariadna affirms that she became a teacher once she entered a classroom, while Carmen also includes her undergraduate education as part of her teaching experience. Elijah is sure that she became an English language teacher during her undergraduate studies and includes her teaching practicum as a relevant part of her education.

In effect, teachers' learning and development, and the context of teachers' learning, are key components in teachers' careers, which is why teachers cannot be detached from our sociocultural realities because no theory is enough to fill that gap (Hammerness, DarlingHammond, \& Bransford, 2005). The path they have walked to become English language teachers has been mediated by their academic and professional experiences and started before graduation; this is a piece of evidence of the important role that teacher educators have and of the relevance of content knowledge and pedagogical practice to shape their teaching careers.

\section{How Do We Develop Our Teaching Identity?}

My education as a teacher, the opportunities for professional development, and my teaching practice along the years have helped me develop a teaching identity that illustrates all the experiences lived, and which differs from those of colleagues I have come across. Developing a teacher identity is thus the result of what happens before, during, and after a teacher education program. Nieto (2003) supports this idea as she affirms, "teachers do not leave their values at the door when they enter the classrooms... They bring their entire autobiographies with them: their experiences, identities, values, beliefs, attitudes, hang-ups, biases, wishes, dreams, hopes" (p. 24).

Notwithstanding, Farrell (2015) introduces the terms a reality check and a reality shock to exemplify how little prepared novice teachers are when they enter the profession and start to build their identity (see also Bonilla \& Cruz, 2014; Cruz, 2018). In my view, such identity is related to the nurtured development of teaching that is built at college, which could be positive

or negative depending on their experience, the accompaniment they have from colleagues and supervisors, and the rapport they get to build with students. Now, this experience, if positive, can reaffirm their identity and make them more reflective and committed teachers; however, if negative, it might result in teacher attrition, which is a common event along the first five years of teaching. 
Accordingly, Faez and Valeo (2012) establish that the decisions that teacher education programs make about what to teach are pivotal in the preparedness that English language teachers gain, and, thus, in the perception they have about their skills to teach, which will influence their identity construction. Faez and Valeo (2012) state that "teachers' beliefs and perceptions about their teaching skills have a strong impact on their teaching effectiveness" (p. 452). Hence, teaching practices that result in successful experiences help teachers gain confidence and develop their identity.

Farrell (2015) highlights the importance of the novice years of teaching that can be smoothed through "novice-service language teacher education" (p. 12). He proposes programs in which novice teachers have this accompaniment and more preparation in terms of "knowledge, skills, awareness" (p. 6) that better prepare them to successfully face the school setting. Although helpful, it is little likely for universities to develop programs like these, unless they are part of an ongoing research project that allows them to be in contact with alumni. If this was possible, teacher educators could provide opportunities for reflection based on novice teachers' specific experiences, but not necessarily prepare them for pre-established situations, given the contextual discrepancies that exist. There are no magic recipes, therefore, teachers need to be creative and work with what they have at hand, always aware of their teaching context; that is, "particularity, practicality, and possibility" (Kumaravadivelu, 2001, p. 538).

Accordingly, Kubanyiova (2018) calls for teacher education that makes meaning and thus makes sense. This is a call for reflection in education that prioritizes social work and adaptation to context-specific education, which will indeed be an alternative to help develop teacher identity as it advocates for teachers' voice and action, for the validation of local and contextual knowledge, and for social transformation through teaching. Kubanyiova declares that teachers have traditionally focused on "language structures and culturally responsive language pedagogies", and proposes "a view of language as a meaning making practice situated in specific social encounters, place and times (a sociocultural approach)" (2018, p. 2).

Terms such as reflective practice, critical inquiry, and creativity are part of Kubanyiova's (2018) discourse, as she poses the need of educating language teachers in the age of ambiguity; teachers who experience, first hand, what it is like to live in other languages, "in contexts in which multilingualism might be perceived as a stigma, a sign of privilege, or a genuine opportunity to enter into an open and creative relationship with the Other" (p. 8). That otherness is approached by Kumaravadivelu (2012) while he illustrates the most salient characteristics of modernism and postmodernism in the construction of identity, in which the first one presents identity as bounded and imposed by family and societal rules, while in the latter identity is constructed, fluid, amorphous, and fragmented. Kumaravadivelu (2012) also affirms that globalism is a crucial factor in identity formation because of the shrinking of the world, thanks to communication flow. Colombian scholars have also studied this 
topic (for instance, Cruz, 2018; Durán, Lastra, \& Morales, 2017). Cruz (2018) explores how teachers' knowledge coming from local experiences in rural Colombian contexts has helped built their identity and value the resources they have at hand.

All of that said, what teacher educators can do as concerns pre-service teachers' identity development is to awaken the need for reflection on their teaching knowledge and action, through the construction of narratives that unveil those experiences. In the following, teachers' voices about teaching identity development are presented.

\section{How did you develop your teaching identity?}

\begin{tabular}{|c|c|}
\hline Marcela & $\begin{array}{l}\text { When I enrolled in modern languages, the curriculum was new and my classmates } \\
\text { and I were the first to register in that undergraduate program. Unfortunately, } \\
\text { the new program did not have a strong pedagogical component, which made } \\
\text { me have a hard time once I started teaching. I always felt that I needed to } \\
\text { learn a lot more to do my job well. The little knowledge I have so far has been } \\
\text { learned from practice, from studying different English methodology books, } \\
\text { from other colleagues' experience, from training courses and from teaching. }\end{array}$ \\
\hline Carmen & $\begin{array}{l}\text { I believe I was predestined to be a teacher. I've had many experiences during my life } \\
\text { and for sure, I've forgotten many of them. However, I must say there is something I } \\
\text { haven't been able to forget doing: teaching my first lesson, not an English one, though, } \\
\text { when I was five years old. I can still remember teaching some small girls of my age, } \\
\text { how to read in Spanish. I had learned to do it from my mom who wasn't a teacher but } \\
\text { had a "how to help someone learn vocation." Also [,] when I happened to explain a } \\
\text { topic to my classmates at school or university, I really liked doing it. Being a teacher is } \\
\text { something I enjoy a lot no matter how many times I can't achieve my expectations. }\end{array}$ \\
\hline Paul & $\begin{array}{l}\text { It all started when I was in my first teaching practicum in a high school that } \\
\text { was full of conflicts and violence and although young, I had to assume my } \\
\text { identity as a teacher and convince my students that literature was something } \\
\text { important for their lives. Then, little by little, I started adding some elements } \\
\text { and developing my professional identity. The places I have taught and } \\
\text { the students I have had, had made me the kind of teacher I am. }\end{array}$ \\
\hline Ariadna & $\begin{array}{l}\text { I consider that it happens every single time when interacting with } \\
\text { my students, in groups or individually. The way I like to share my } \\
\text { learning experiences and to respect their voices, cultural backgrounds } \\
\text { and likes, allow me to integrate them into my teaching plan. }\end{array}$ \\
\hline Elijah & $\begin{array}{l}\text { I believe I have developed my teaching identity throughout my life working } \\
\text { experience. As time has passed, I have changed my teaching style, I mean every } \\
\text { time I have had the opportunity to teach, I have learned a lot of things that have } \\
\text { molded my identity. Right now, I can say I have really felt the passion for teaching } \\
\text { English. Every time I enter a classroom, I learn something new from students and } \\
\text { the class itself. These things have made think about what teaching really means. }\end{array}$ \\
\hline
\end{tabular}


Marcela started to develop her teaching identity once she began teaching, while Paul feels that it started while he was in his teaching practicum because of the roles he had to assume as a teacher to help students change their attitudes. Carmen, predestined to be a teacher, has a born (Freeman, 2016) identity that has been nurtured during her whole life through education and experience. Ariadna's interaction with her students has contributed to her cultural understanding of difference; while Elijah reassures her identity through the passion, she feels that she enters the classroom every day.

In fact, these teachers' identity construction has been an ongoing journey that has included moments of teacher education, development, and practice. For instance, they express the need for inquiry and reflection to adapt their teaching practices. This 'adaptive expertise' in terms of Hammerness, Darling-Hammond, and Bransford (2005) "provides an appropriate gold standard for becoming a professional" (p. 360). Accordingly, Faez and Valeo (2012) advise on the need to build a critical frame that prepares us to face reality.

Hence, remembering that the development of knowledge, skills, and attitudes surpasses pre-service education programs, teachers come to value the benefits of experience in teaching by proposing innovation even in situations in which frameworks and policies suggest the opposite. As such, Hammerness, Darling-Hammond and Bransford (2005) state, "over time, teachers progress from learning the basic elements of the task to be performed and accumulating knowledge about learning, teaching, and students to making conscious decisions about what they are going to do" (p. 380). That is, teachers construct their identity "actively on an on-going basis" (Kumaravadivelu, 2012, p. 10).

\section{What Knowledge Makes Us Become the Kind of Teachers We Are?}

The changing times and the advance of technology, which have resulted in the shrinking of the world in terms of communication and access to information, have surely affected how teachers gain knowledge and how they put it into practice. English language teachers have opportunities to learn the language outside the classroom, even if they do not go to an English- speaking country. Although there are no pre-established curricula, there are certain minimums that English language teachers are to know in order to succeed. Several authors have suggested those minimum requirements in the last three decades, as Álvarez Valencia (2009), Fandiño (2013), Freeman (2018), and Shulman (1987). To mention some, Shulman (1987), who pioneered in the area, argues that content knowledge, general pedagogical knowledge, curriculum knowledge, and pedagogical content knowledge are essential elements that teachers need to know. More recently, Freeman (2018) proposes the need to go from work-driven to field-driven knowledge, and to analyze content, teachers, learners, pedagogy, and teacher education. Furthermore, Johnson and Golombek (2018) emphasize what teacher educators do and say, and the reasoning behind that, as key elements in teacher 
education. After analyzing several proposals of what teachers should know, Fandiño (2013) suggests that "efforts should be made to conceptualize what Colombian language teachers need to know about teaching and learning, and how their knowledge, beliefs, and attitudes inform their practices" (p. 84).

Common to the proposals presented above is the establishment of linguistic, content, and pedagogical knowledge at the core of teacher education programs. More recently the inclusion of technology, context-based teaching, and agency have been included, which reflect the dynamics of changing times where globalization breaks boundaries, but the need to value local realities remains essential.

Accordingly, Farrell (2015) contends that novice teachers face a very different world once they graduate. Notwithstanding, in my context, the teaching practicum is an opportunity for pre-service teachers to start facing that reality, not to mention that many students have gotten teaching jobs by the time they have reached the fourth year of their undergraduate program. This means that the knowledge that teachers need is not contested once they graduate, but way before. We as teacher educators can therefore start reflecting with last year pre-service teachers on those realities that they are facing regarding knowledge and preparedness in all the domains that the profession requires.

Shulman's (1987) proposal is a good counterpart for Freeman's (2018), and Johnson and Golombek's (2018) proposal because while the last two present a current view of English language teaching that contrasts with the past decades, Shulman's reflects on how knowledgebased teaching was conceived before, with a projection to the future. The first call that I take from Shulman is the reflection he engages in on not ignoring teaching in the past, which is a counterargument to Freeman's (2018) proposition of unlearning previous knowledge to gain new knowledge. Indeed, it is essential to take the past as the basis to build on the future.

Standardization and complying with policies are at the root of educational reforms, and this is a fact upon which Shulman (1987) remarks. Shulman does not question educational reform, but attempts at proposing an analysis of knowledge and the sources of that knowledge that teachers need to have to meet the standards that such reform requires, including basic skills that teachers need to develop, such as content knowledge, pedagogical skills, curriculum knowledge, and knowledge of goals, learners, and educational contexts.

Shulman (1987) highlights the importance of pedagogical content knowledge, which is a phrase he has been famous for because it gives teachers the ability to put knowledge at the level of the student, since, as he introduces it, "the teacher can transform understanding, performance skills, or desired attitudes or values into pedagogical representations and actions... Teaching necessarily begins with a teacher's understanding of what is to be learned and how it is to be taught" (p. 7). He acknowledges, however, that individual differences and achievements that teachers gain can neither be taught nor measured. 
Shulman's (1987) research, compared to more current studies, also includes basic elements such as reflective practice that are essential for teachers to develop. Furthermore, he presents a "model for pedagogical reasoning and action" (p. 15), which fosters new comprehensions and creativity. Shulman's pedagogical knowledge process proves how once teachers are able to understand, analyze, and adapt their teaching, they can innovate and evaluate their practices. Although he favors reforms for the professionalization of the teaching profession, he also asserts, "we have an obligation to raise standards in the interests of improvement and reform, but we must avoid the creation of rigid orthodoxies. We must achieve standards without standardization" (p. 20). Additionally, Johnson and Golombek (2018) present a solid proposal to transform language teacher education (LTE) pedagogy, after reflecting on the where, why, how, and what of teachers. They provide a state of the art on knowledge-base of LTE and attempt to mediate among the various contexts and sociocultural backgrounds of teachers from a Vygotskian perspective.

Due to the fact that most research focusing on teachers has not explored the pivotal role of teacher educators, Johnson and Golombek now study "what teacher educators do and say" (2018, p. 2). They assert that "today, LTE programs are in a vast array of sociocultural, educational, economic, and political contexts and these contexts matter" (p. 2). This means that as teacher educators, we cannot detach ourselves from the sociocultural contexts that surround pre-service teachers, nor from the potential realities that they will face once do they join the work force. On the other hand, I identify with their view of engaging in a self-inquiry dimension through teacher narrative because reflecting and narrating what teachers are experiencing in the classroom might bring alternative and creative solutions to everyday issues.

On the other hand, Freeman's (2018) ideas of knowledge-base in language teacher education conceive how different terms in language teaching have changed in the last decades, thanks to the development English teaching has undergone and on the focus from learners to contents. The revisiting of terms is the result of the expansion of the inner circles (Freeman, 2018) that have mandated what is to be taught and how. Favoring centralism, eurocentrism, native-speakerism, and whiteness has decayed in the last years, as the English teaching community worldwide has expanded its views thanks to advocates coming from more peripheral (Canagarajah, 2005, Kumaravadivelu, 2012, 2016) origins. This has expanded teachers' knowledge and views of content to welcome sociocultural language teaching. In this way, peripheral users of the language have, little by little, gained space in the language-teaching field, promoted the development of policies, and designed curriculum that is inclusive of local practices.

Concerning local knowledge, Freeman (2018) mentions the tension between globalization and local practices. He asserts, "questions about what it means to teach 'well' are often caught in tensions between global definitions of ELT professionalism and the day-to-day practices of ELT which are profoundly local" (p. 6). I ponder that those tensions should be 
negotiated among the stakeholders to have a balance between what is needed for students to become global citizens and the inclusion of local knowledge to reinforce identity; that is, the relation between new learning with their own cultural practices.

It is remarkable how Freeman (2018) presents the two-folded relationship of central and peripheral teachers because the first learn from diversity in their classrooms while preparing NNS teachers, and the latter provide innovative teaching practices where the local is present through translanguaging and developing intercultural understandings. This is a good way of acknowledging what NS and NNS teachers do for developing the profession. Perceptions about who teaches have changed, giving way to more NNS teachers who have been able to position themselves in the field. The above discussion is well evident in publications produced by Colombian scholars (as in Álvarez Valencia, 2009; Arboleda \& Castro, 2012; Fandiño, 2013; Viáfara, 2016) who, with a global view, have explored local English teaching practices, teachers' perceptions about what to teach and how to teach it, as well as their concerns when dealing with their language skills and pedagogical knowledge. As an example, Álvarez Valencia (2009) explores Colombian teachers' knowledge base and perceptions, which, as he posits, goes beyond formal knowledge to permeate context and experiences. Similarly, Arboleda and Castro (2012) exhibit teachers' and students' ideas behind a nativelike accent. The discussion that follows, based on participants' perceptions, better exemplifies this issue.

\section{What knowledge has made you become the kind of teacher you are?}

I could not speak of a specific type of knowledge; I would say that there are many things at stake: Experience (trial and error), some aspects we internalize from different training courses, sharing experiences with other colleagues around a cup coffee or in more formal places like university. In addition, other aspects that I consider are

Marcela part of this process are the attitudes and qualities that one has as a teacher: having an open attitude to be in constant learning and implement new strategies, discipline, responsibility, and commitment to work. Develop emotional intelligence that I think is an essential aspect of our teaching work. In short, knowledge is not easy to measure or describe and even less when it is related to the future of a teacher.

First of all, my own language learning and my understanding of how students learn more effectively and meaningfully. I believe that effective teaching is built upon learning; that is, how students learn determines teaching.

Carmen Second, knowing the power I have to influence my students to be better people and to realize that languages like English can help us broaden our horizon and our vision of a better society.

Finally, taking pride of being an English teacher makes me feel at ease and motivated to go ahead helping students learn. 


\begin{tabular}{|l|l|}
\hline Paul & $\begin{array}{l}\text { The knowledge about linguistics, discourse analysis, and language teaching that I } \\
\text { got in graduate school. The knowledge of the context where I teach allows me } \\
\text { to understand the nature of the institution and the environment where I work. }\end{array}$ \\
\hline Ariadna & $\begin{array}{l}\text { Every day I try to improve as a person, as a teacher, etc., I know } \\
\text { that knowledge isn't a static process so I have to study every } \\
\text { single day and try to be closer to this century students. }\end{array}$ \\
\hline Elijah & $\begin{array}{l}\text { I could say the knowledge I learned when I studied in college and from my } \\
\text { postgraduate studies have contributed to my professional growth. Besides, I have } \\
\text { been fond of technology, so I have taken advantage of ICT to update myself. }\end{array}$ \\
\hline
\end{tabular}

Marcela cannot describe specific knowledge, but she asserts that becoming a teacher is made up of several experiences that help construct that knowledge along the years. Paul is clear in affirming the relevance that specific content knowledge and context have in language teaching. Carmen affirms that the knowledge of the language, the know-how of teaching and the passion for this profession are key elements that make teachers the kind of educators they are. Ariadna learns every day from her students and her practice, always acknowledging the shifting sands that she is to encounter in the classroom. Elijah values the knowledge gained during her academic career and the use of technology for language learning, which have helped her grow professionally.

The way we as teachers conceive and use knowledge highly depends on the moment we are living in our profession. In this line of thought, Hammerness, Darling-Hammond, and Bransford (2005) introduce "knowledge for practice, in practice, and of practice" (p. 382), which is to be taken as a continuum because one practice cannot end where the next one starts. As novice, advanced, or expert teachers (if we ever get to be), we are always acquiring knowledge that we put into practice straightaway, and as we gain knowledge of practice, we understand the need to gain more knowledge to experience a better practice. Therefore, as long as we are reflective practitioners this learning-development process never stops.

\section{What Are Some Sociocultural and Global Issues Behind Teaching English?}

Kumaravadivelu (2012), as an advocate for language teachers from the outer and expanding circles, and of decolonial practices in language teaching, introduces enlightening ideas towards language learner's identity construction as regards globalization. His notion of agency and the breaking with Eurocentric traditions to embrace context-based language teaching that is rooted in the particularities of its beneficiaries is at the base of its discussion. He presents language classes as a space of complex identity formation and advises of the need to "break dependency from Western-oriented, centered-based knowledge systems that 
carry an indelible colonial coloration" (p. 14). He, citing Foucault, proposes an epistemic break, "a postmodern concept of self-identity; a reorganization of knowledge systems" (p. 14).

That epistemic break in English as an International Language is the breaking with the idolatry of the "NS and the NS competence" (p. 15). He then asserts "a meaningful break from this epistemic dependency if we are serious about sanitizing our discipline from its corrosive effect and sensitizing the field to the demands of globalism and its impact on identity formation" (p. 15). To this, I would add that this is an extreme assertion because, although as peripheral English teachers, or as explained by Canagarajah (2005), we, those teachers from the outer circles, need to develop agency; we cannot deny the value of those who use the language on a daily basis for real-life purposes. Scholars in the Colombian context are also aware of the need to propose English language teaching practices that are grounded in local awareness, and have thus explored possibilities for developing sociocultural consciousness, critical interculturality, and cultural agency (see Bautista Pérez, 2017; Bonilla \& Cruz, 2014; Calle Díaz, 2017; Granados Beltrán, 2016; Ramos Holguín et al., 2012; Viáfara \& Ariza, 2015). In this line, Ramos Holguín et al. (2012) encourage students' intercultural understanding in a rural school by including their context in the lessons to acknowledge the differences that exist between rural and urban education. These authors altogether promote spaces where language learning involves the acknowledging of multiple forms of communication and the inclusion of learners' experiences and sociocultural backgrounds.

McKay (2018) also addresses topics of current concern for language educators. She points out at the difference among World Englishes (WE), English as a Lingua Franca (ELF), and English as an International Language (EIL), which although all may seem alike, have differences as to how they are conceived and their implications for users and teachers. She points out the tension that exists among the varieties of English used nowadays, who uses them, and how they are used, under what pragmatic, and sociocultural experiences. Linguistically speaking, Kachru (1983, as cited in McKay, 2018) argues, "Englishes cannot be judged by the norms of English in Inner Circle countries. Rather, the form and function of new Englishes must be considered according to the context of situation which is appropriate to the variety, its uses, and users" (p. 4). However, one must bear in mind that there are minimum requirements necessary for Englishes to be mutually intelligible, otherwise, communication will be hindered by the bridge opened through form variation.

Sifakis (2007), drawing on Mezirow's framework for adult education, proposes some steps for the education of teachers of English as a Lingua Franca (ELF). His main concern is to acknowledge the relevance that ELF has gained and to prepare teachers that have the necessary knowledge and strategies to position it in the language classroom. The author provides a literature review and endorsement as to why English should be studied as a Lingua Franca, and gives examples of authors and studies aiming this way; however, considering 
the fact that the kind of interaction that is encouraged is only among NNSs, this is an unrealistic aim, in an urge to delete any trace of the NS who has been favored for decades. This proposal goes to the other end and falls into the same ideas of one position considered to be the best. What is more, Sifakis recognizes the pitfalls of the proposal in the discourse that NNSs will hold among themselves, which might be lexico-grammatical issues. In the following, practitioners voice their take on this issue:

\section{What are some sociocultural and global issues behind teaching English?}

\begin{tabular}{|c|c|}
\hline \multicolumn{2}{|r|}{ What are some sociocultural and global issues behind teaching English? } \\
\hline Marcela & $\begin{array}{l}\text { As we live in a globalized and technology-mediated world, there are many cultural } \\
\text { and global aspects behind. For example, the ways of behaving in certain situations, } \\
\text { the expressions and mode of speaking in different contexts (register). As for } \\
\text { gastronomy, depending where you are, there is a whole protocol that must be } \\
\text { followed. Despite globalization, countries continue to maintain their culture and } \\
\text { idiosyncrasies. The use of social networks makes certain type of behavior typical: } \\
\text { Phrases that are only used when communicating online: use of abbreviations, } \\
\text { foreign words, symbols, in short, a whole new communication system. }\end{array}$ \\
\hline Carmen & $\begin{array}{l}\text { Based on my experience as an English teacher, sociocultural and global issues are } \\
\text { related to the social representations of what being a teacher means and implies. } \\
\text { In a country like Colombia, for instance, since English is a foreign language, in } \\
\text { many cases, students don't find it necessary to learn this language so teachers may } \\
\text { feel frustrated. All the policies established by the Ministry of Education, which } \\
\text { are underpinned by standards taken from the Common European Framework } \\
\text { of Reference for Languages, seem to not apply to our real contexts and both } \\
\text { teachers and learners remotely visualize their expectations. However, despite being } \\
\text { a challenge, teaching English can help broaden our horizon and our vision of the } \\
\text { world considering all the contributions we can make for its transformation. }\end{array}$ \\
\hline Paul & $\begin{array}{l}\text { There are issues going on in regards to decoloniality, native-speakerism, intercultural } \\
\text { competence, multiliteracies, and the like. Language teachers commonly have } \\
\text { opportunities to work abroad and gain experience, which help us understand } \\
\text { the importance of context in teaching. For example, I agree with the idea } \\
\text { that native speakers are not always the best but, in the US, I was a beneficiary } \\
\text { of my condition as a native speaker of Spanish to work in a college. } \\
\text { I have to position myself as a globally-minded teacher who knows about } \\
\text { the local and global matters and can link them in my classes. }\end{array}$ \\
\hline Ariadna & $\begin{array}{l}\text { It is important to recognize the attitudes, cross cultural differences, } \\
\text { cultural deprivation, identity, culture change, discrimination, } \\
\text { ethnic and many factors behind the language. }\end{array}$ \\
\hline
\end{tabular}




\begin{tabular}{|l|l|}
\hline Elijah & $\begin{array}{l}\text { Concerning socio cultural issues, I consider students' academic } \\
\text { background remarkably influences their performance in class. I think } \\
\text { this is one of the main issues I have had to face when teaching. } \\
\text { Another important issue, in my particular case, is the fact my students } \\
\text { are not interested in learning English meaningfully since they think } \\
\text { they have to learn it as a requirement to graduate from college. }\end{array}$ \\
\hline
\end{tabular}

Marcela argues that teachers have to be aware of specific knowledge and attitudes we need to gain to be part of this globalized world; although social networks have standardized certain language and behavior, there are specific cultural practices that countries adhere to and which language learners need to know. Opening our horizon, transforming ourselves and the language we teach are part of the sociocultural and global issues that Carmen encounters as an English teacher. Aligned with these ideas, Paul mentions decoloniality as a relevant sociocultural and global issue that favors the development of a global mind that goes beyond native-speakerism. Elijah finds a barrier in the reasons her students have for learning, while Ariadna acknowledges the intercultural issues, we face and need to be prepared for while learning, teaching, and living the English language.

Accordingly, Kumaravadivelu (2018) maintains that inherent to globalization "people are simultaneously coming together and pulling apart... The interconnectedness between cultural globalization, identity formation, and English language education has started getting the attention it truly deserves from educators" (pp. 11-12). In fact, English language teachers are now more aware of their social responsibility to nurture sociocultural practices that are inclusive of globalism and that start with the acknowledgement of local realities. In this regard, the Colombian context has witnessed the raising of teaching practices that explore local sociocultural realities (Cruz, 2018), are concerned with teachers' knowledge (Álvarez Valencia, 2009) and belief in the importance of telling our stories (Durán, Lastra, \& Morales, 2013). These studies are inclusive of global sociocultural knowledge to nurture more localized language teaching and learning.

\section{Conclusions}

The discussion raised in this paper was triggered by the big responsibility that we face as teacher educators, and by the need to research and reflect on what is at stake in language teaching. Narratives unveil realities and discussions about real-life issues present in the language classroom and provide opportunities for making informed decisions about the essential elements for pre-service teachers to be educated with a global mind that starts with and goes back to local knowledge. 
As such, the topic under discussion included current terms that have shaped English language teaching and helped guide our classroom practices. It also revolved around four questions that provoked narratives from teacher educators, in which it was commonplace to read that we become English teachers during a teacher education program or before, through the many opportunities we have to teach and from people around us.

Additionally, a teaching identity is influenced by the plethora of opportunities we have for becoming the kind of teachers we are, which is marked by our teacher education and experience. Moreover, knowledge in our profession comes from books, teachers and ultimately, but most importantly, from classroom practice, where we learn about the many possibilities and the astonishing diversity that we are never taught. Along these lines, becoming aware that knowledge is beyond textbooks and university lectures, we start to open ourselves to a sociocultural language teaching that is global and local at the same time.

\section{References}

Adichie, C. N. (2009). The danger of a single story. Retrieved from https://www.ted.com/talks/chimamanda_adichie_the_danger_of_a_single_story?language $=$ en

Álvarez Valencia, J.A. (2009). An exploration of Colombian EFL teachers' knowledge base through teachers' reflection. Linguagem \& Ensino, Pelotas, 12(1), 73-108.

Arboleda, A., \& Castro, A. (2012). The accented EFL teacher: Classroom implications. Profile: Issues in Teachers' Professional Development, 14(2), 45-62.

Bautista Pérez, N. (2017). Constructing sociocultural awareness from the EFL classroom. Gist: Education and Learning Research Journal, 15, 149-172.

Bonilla, S., \& Cruz, F. (2014). Critical socio-cultural elements of the intercultural endeavor of English teaching in Colombian rural areas. Profile: Issues in Teachers' Professional Development, 16(2), 117-133.

Canagarajah, S. (Ed.). (2005). Reclaiming the local in language policy and practice. Lawrence Erlbaum.

Calle Díaz, L. (2017). Citizenship education and the EFL standards: A critical reflection. Profile: Issues in Teachers' Professional Development, 19(1), 155-168.

Cruz, F. (2018). The wisdom of teachers' personal theories: Creative ELT practices from Colombian rural schools. Profile: Issues in Teachers' Professional Development, 20(2), 65-78.

Dewey, J. (1916). Democracy and Education. The Macmillan Company.

De Mejía, A. (2006). Bilingual education in Colombia: Towards a recognition of languages, cultures and identities. Colombian Applied Linguistics Journal, 8, 152-168.

Durán, N., Lastra, S., \& Morales, A. (2013). Autobiographies: A way to explore student-teachers' beliefs in a teacher education program. Profile: Issues in Teachers' Professional Development, 15(2), 35- 47. 
Durán, N., Lastra, S., \& Morales, A. (2017). Beliefs of pre-service teachers about English language teaching: Course and practice. Folios, 45, 177-193.

Espinosa-Vargas, A. (2019). Nativespeakerism in a Colombian bilingual context? Quaestiones Disputatae-Temas en Debate, 12(24), 97-111.

Faez, F., \& Valeo, A. (2012). TESOL teacher education: Novice teachers' perceptions of their preparedness and efficacy in the classroom. TESOL Quarterly, 46(3), 450-471.

Fandiño, Y. (2013). Knowledge base and EFL teacher education programs: A Colombian perspective. Ikala, 18(1) 83-95.

Farrell, T. (2015). Second language teacher education: A reality check. In T. Farrell (Ed.), International perspectives of English language teacher education (pp. 1-15). Palgrave Macmillan.

Freeman, D. (2016). Educating second language teachers. The same things done differently. Oxford University Press.

Freeman, D. (2018). Arguing for a knowledge-base in language teacher education, then (1998) and now (2018). Language Teaching Research, 1-12.

Granados Beltrán, C. (2016). Critical interculturality. A path for pre-service ELT Teachers.

Ikala, 21(2), 171-187.

Hammerness, K., Darling-Hammond, L., \& Bransford, J. (2005). How teachers learn and develop. In L. Darling-Hammond \& J. Bransford (Eds.), Preparing teachers for a changing world (359-389). Josey Bass.

Kumaravadivelu, B. (2001). Towards a postmethods pedagogy. TESOL Quarterly, 35(4), 537-560.

Kumaravadivelu, B. (2012). Individual identity, cultural globalization, and teaching English as an international language. In L. Alsagoff, S. L. McKay, G. Hu, \& W. Renandya. Principles and practices for teaching English as an international language (pp. 9-24). Routledge.

Kumaravadivelu, B. (2016). The decolonial option in English teaching. Can the subaltern act? TESOL Quarterly, 50(1), 66-85.

Kumaravadivelu, B. (2018). Cultural globalization and language education. Yale University Press.

Kubanyiova, M. (2018). Language teacher education in the age of ambiguity: Educating responsive meaning makers in the world. Language Teaching Research, 1-11.

Johnson, K., \& Golombek, P. (2011). The transformative power of narrative in second language teacher education. TESOL Quarterly, 45(3), 486-509.

210 Johnson, K., \& Golombek, P. (2018). Informing and transforming language teacher education pedagogy. Language Teaching Research, 1-12.

McKay, S. L. (2018). English as an international language: What it is and what it means for pedagogy. RELC Journal, 1-15.

Nieto, S. (2003). What keeps teachers going? Teachers College.

Ramos Holguín, B., Aguirre Morales, J., \& Hernández, C. (2012). A pedagogical experience to delve into students' sense of cultural belonging and intercultural understanding in a rural school. HOW, 19(2), 123-145. 
Shulman, L. (1987). Knowledge and teaching: Foundations of the new reform. Harvard Educational Review, 57(1), 1-23.

Sifakis, N. C. (2007). The education of teachers on English as a lingua franca: A transformative perspective. International Journal of Applied Linguistics, 17(3), 355-375.

Viáfara, J. (2016). "I'm missing something." (Non)nativeness in prospective teachers as Spanish and English speakers. Colombian Applied Linguistics Journal, 18(2), 11-24.

Viáfara, J., \& Ariza, J. A. (2015). From awareness to cultural agency: EFL Colombian student teachers' travelling abroad experiences. Profile: Issues in Teachers' Professional Development, 17(1), 123-141. 